\title{
LEI DE INOVAÇÃO TECNOLÓGICA: Os aspectos legais da inovação no Brasil
}

Jardel Luís Vettorato ${ }^{1}$

RESUMO: O presente artigo pretende de modo sucinto abordar os principais aspectos e instrumentos legais previstos pela lei de inovação tecnológica a fim de incentivar o desenvolvimento pesquisa, desenvolvimento e inovação no país. A lei de inovação visa alterar o atual cenário das pesquisas no país, bem como pretende proporcionar uma maior interação entre as universidades e os meios de produção brasileiros. Um dos grandes objetivos da lei é possibilitar a transferência do conhecimento produzido no ambiente acadêmico em prol da sociedade.

PALAVRAS-CHAVE: Desenvolvimento. Interação. Conhecimento.

\section{LAW OF TECHNOLOGICAL INNOVATION: The legal aspects of innovation in Brazil}

ABSTRACT: This article intends to board briefly the main aspects and legal instruments in the law of technological innovation in order to encourage the development research, development and innovation in the country. The law of innovation aimed at amending the current scenario of research in the country and intends to provide greater interaction between universities and the means of production Brazilians. One of the major purposes of the Act is to enable the transfer of knowledge produced in the academic environment for the benefit of society

KEY-WORDS: Development. Interaction. Knowledge.

\section{INTRODUÇÃO}

\begin{abstract}
A ciência esta destinada a desenvolver um papel cada vez mais preponderante na produção industrial. E as nações que deixarem de entender esta lição hão inevitavelmente de serem relegadas à posição de nações escravas: cortadoras de lenha e carregadoras de água para os povos mais esclarecidos. ${ }^{2}$
\end{abstract}

Assim, o conhecimento é a bússola para o desenvolvimento. Deste modo, as riquezas das nações não são mais determinadas pela quantidade dos seus recursos naturais ou minerais, mas sim pelo potencial de se produzir e de se proteger o conhecimento pátrio e revertê-lo em benefício de sua população.

A atual sociedade vive em constantes transformações nos campos sociais, econômicos, políticos ou tecnológicos. As dinamicidades das relações do globo estão provocando uma gama de alterações nas estruturas sociais dos povos, estamos em contato direto e instantâneo com qualquer pessoa do mundo em qualquer lugar planeta.

\footnotetext{
1 Acadêmico de graduação do $7^{\text {a }}$ semestre do curso de Direito da Universidade Federal de Santa Maria, membro do Grupo de Pesquisas em Propriedade Intelectual - GPPI/UFSM. vettorato.jardel@gmail.com

2 RUTHERFORD, Lord citado no documento "Ciência e Pesquisa - Contribuição de Homens do Laboratório e da Cátedra à Magna Assembléia Constituinte de São Paulo”, que propôs a criação da Fapesp em 1947.
}

(C) 2008. Departamento de Direito da UFSM. Todos os direitos reservados. 
Tais avanços, somente foram possíveis com o advento de inúmeras tecnologias que nasceram de numerosas pesquisas científicas e tecnológicas.

Desde o seu surgimento, o homem busca incansavelmente aprender a aperfeiçoar as coisas que estão ao seu redor a fim de melhorar a sua comodidade e o seu bem estar. Sempre buscou desenvolver através do conhecimento adquirido e através da observação dos fatos da natureza ou mediante a realização de pesquisas científicas criar novas tecnologias. Convém lembrar, que o aperfeiçoamento dos instrumentos de trabalho, a inovação dos métodos de produção, da construção, da captação e geração de energia foram imprescindíveis para a prosperidade de antigas civilizações, entre elas, pode-se citar o povo Egípcio, que se destacou em várias áreas, tanto na medicina através dos processos de mumificação e cirurgias, quanto na engenharia, visto que as construções das gigantescas pirâmides ainda são consideradas um enigma nos tempos modernos.

A autonomia científica e tecnológica do mundo globalizado é auferida pela capacidade das nações produzirem, absorverem e transmitirem conhecimento, tornando seus setores produtivos modernos, avançados e competitivos. Dessa forma, é necessária a implantação de vários conjuntos de ações integradas e harmônicas entre si objetivando o desenvolvimento científico e tecnológico do país. Tais medidas devem ser devidamente articuladas e integradas entre todos os agentes da sociedade, logo, deve coexistir a participação de todos os agentes do Estado (União, Estados, Municípios); da comunidade científica, dos setores privados, dos setores empresariais, dos movimentos sociais, ou seja, de toda a comunidade brasileira que almeja o desenvolvimento nacional.

Todas essas ações devem ser instrumentalizadas mediante políticas públicas que vise o desenvolvimento econômico e social do país. É necessário que haja o envolvimento de todos os entes do estado brasileiro a fim de promover o progresso e convertê-lo no bem estar da população, com melhoria da qualidade de vida da população, da redução das desigualdades sociais, bem como a ampliação do acesso à educação, cultura, lazer e saúde.

Neste sentido, o governo federal preocupado em promover o progresso econômico e social do país através da pesquisa e desenvolvimento (P\&D), promulgou no dia 02 de dezembro de 2004, a Lei de incentivo à inovação, à pesquisa científica e tecnológica no ambiente produtivo (Lei ${ }^{\circ}$. 10. 973/04), comumente chamada de Lei de inovação tecnológica e delineou as diretrizes gerais para o fomento das pesquisas 
científicas e tecnológicas, bem como as bases legais para a interação entre as universidades e as empresas para o desenvolvimento científico e tecnológico, além disso, disciplinou as regras para proteção da produção intelectual brasileira no âmbito das Instituições Científicas e Tecnológicas (ICT’s).

Portanto, o presente artigo pretende abordar os aspectos legais e os instrumentos fornecidos pela lei de inovação tecnológica para incentivar as pesquisas científicas no país. Do mesmo modo, objetiva-se abordar o tratamento delineado pela lei sobre a propriedade intelectual decorrente do desenvolvimento das pesquisas em C\&T\&I (ciência, tecnologia e inovação).

\section{DA MATRIZ CONSTITUCIONAL PARA O PROGRESSO CIENTÍFICO E TECNOLÓGICO DO BRASIL}

A Constituição Federal brasileira no intuito de estimular o desenvolvimento nacional traçou inúmeras diretrizes. Desta maneira, estabeleceu que a união indissolúvel dos Estados e Municípios e do Distrito Federal, que formam o Estado Democrático de Direito Brasileiro, têm como fundamentos da República Federativa do Brasil a adoção de políticas a fim de garantir a soberania nacional, os direitos de cidadania, o pluralismo político, a manutenção dos valores sociais do trabalho e a livre iniciativa, bem como a dignidade da pessoa humana ${ }^{3}$.

Da mesma forma, a ordem jurídica constitucional delineou os objetivos fundamentais do Estado Brasileiro, quais sejam; construir uma sociedade livre; justa e solidária; garantir o desenvolvimento nacional; erradicar a pobreza e a marginalidade e reduzir as desigualdades sociais e regionais; promover o bem de todos, sem preconceitos de origem, raça, sexo, cor, idade e quaisquer outras formas de discriminação ${ }^{4}$. Assim, a constituição indica as diretrizes que norteadoras das políticas a serem adotadas pelos governantes para o progresso econômico e social do país.

\footnotetext{
3 Os fundamentos da República Federativa Brasileira estão delineados no art. $1^{\circ}$ da Constituição Federal de 1988, eis que segue na íntegra:

Art. $1^{\circ}$ A República Federativa do Brasil, formada pela união indissolúvel dos Estados e Municípios e do Distrito Federal, con stitui-se em Estado Democrático de Direito e tem como fundamentos:

I - a soberania;

II - a cidadania;

III - a dignidade da pessoa humana;

IV - os valores sociais do trabalho e da livre iniciativa;

$\mathrm{V}$ - o pluralismo político.

4 São objetivos fundamentais da República Federativa Brasileira os traçados no art. $3^{\circ}$ da Constituição Federal de 1988.

Art. $3^{\circ}$ Constituem objetivos fundamentais da República Federativa do Brasil:

I - construir uma sociedade livre, justa e solidária;
}

(C) 2008. Departamento de Direito da UFSM. Todos os direitos reservados. 
Nesse liame, com objetivos de fomentar o progresso econômico e social, o governo brasileiro vem apostando em grandes investimentos através de vários planos de ação, principalmente, em setores de infra-estrutura, educação, ciência e tecnologia. Nestes moldes, lançou o Programa de Aceleração do Crescimento (PAC) que visa incentivos em obras estratégicas de infra-estrutura, colocou em prática o Fundo Nacional de Desenvolvimento da Educação Nacional (FNDE) e recentemente, anunciou o Plano de Ação em Ciência, Tecnologia e Inovação (Pacti) ${ }^{5}$, que prevê cerca 40 bilhões em investimentos para incentivar as pesquisas em ciência, tecnologia e inovação ${ }^{6}$ no país.

Além disso, cabe frisar que a carta magna estabeleceu ao Estado brasileiro a competência para gerir e adotar medidas que possibilitem o progresso tecnológico ${ }^{7}$. Deste modo, a fim de regulamentar as disposições constitucionais dos artigos 218 e 219 que dispõem acerca da ciência e da tecnologia promulgou a lei federal 10.973/04, ou mais conhecida como lei de inovação tecnológica.

\section{OS ASPECTOS LEGAIS DA INOVAÇÃO TECNOLÓGICA}

A lei de inovação traça os nortes para incentivar as interações entre as universidades (Instituições Científicas e Tecnológicas) e os setores de produção, a fim de fomentar o desenvolvimento científico e tecnológico do país. A lei também aborda as

\footnotetext{
II - garantir o desenvolvimento nacional;

III - erradicar a pobreza e a marginalização e reduzir as desigualdades sociais e regionais;

IV - promover o bem de todos, sem preconceitos de origem, raça, sexo, cor, idade e quaisquer outras formas de discriminação.

5 PORTAL do Ministério da Ciência e da Tecnologia - MCT. Disponível em http:/ftp.mct.gov.br/prog/pacti/Default.htm . Acessado em 20 de junho de 2008.

6 O plano de ação governamental visa estimular o desenvolvimento de novas tecnologias no intuito capacitarem o setor industrial brasileiro tornando o mais

competitivo, em espacial, os investimentos serão priorizados para atenderem micro-empresas e empresas de pequeno. Disponível em http://www.desenvolvimento.gov.br/pdp/public/arquivos/BNDES-Luciano-Coutinho.pdf. Acessado em 20 de junho de 2008.

7 A Constituição Federal tratou da Ciência e da Tecnologia em dois artigos, artigos 218 e 219, respectivamente.

Art. 218. O Estado promoverá e incentivará o desenvolvimento científico, a pesquisa e a capacitação tecnológicas.

$\S 1^{\circ}$ - A pesquisa científica básica receberá tratamento prioritário do Estado, tendo em vista o bem público e o progresso das ciências.

$\S 2^{\circ}$ - A pesquisa tecnológica voltar-se-á preponderantemente para a solução dos problemas brasileiros e para o desenvolvimento do sistema produtivo nacional e regional.

$\S 3^{\circ}$ - O Estado apoiará a formação de recursos humanos nas áreas de ciência, pesquisa e tecnologia, e concederá aos que delas se ocupem meios e condições especiais de trabalho.

$\S 4^{\circ}$ - A lei apoiará e estimulará as empresas que invistam em pesquisa, criação de tecnologia adequada ao País, formação e aperfeiçoamento de seus recursos humanos e que pratiquem sistemas de remuneração que assegurem ao empregado, desvinculada do salário, participação nos ganhos econômicos resultantes da produtividade de seu trabalho.

$\S 5^{\circ}$ - É facultado aos Estados e ao Distrito Federal vincular parcela de sua receita orçamentária a entidades públicas de fomento ao ensino e à pesquisa científica e tecnológica.

Art. 219. O mercado interno integra o patrimônio nacional e será incentivado de modo a viabilizar o desenvolvimento cultural e sócio-econômico, o bem-estar da população e a autonomia tecnológica do País, nos termos de lei federal.
}

(C) 2008. Departamento de Direito da UFSM. Todos os direitos reservados. 
questões concernentes à proteção do conhecimento intelectual produzido em decorrência dos resultados das pesquisas em C\&T\&I (ciência, tecnologia e inovação), bem como trata a respeito dos instrumentos legais para a realização dos procedimentos de transferência de tecnologia e licenciamento de patentes para exploração comercial.

A lei brasileira possui origem na legislação francesa ${ }^{8}$, na "Loi sur l'innovation et la recherche 1999 - França". O primeiro projeto de lei (PL) foi apresentado no ano de 2000 pelo senador Roberto Freire que transitou nas comissões de constituição e justiça e restou arquivado por despacho presidencial. A comunidade científica do país se mobilizou e começou a debater a importância e a necessidade de uma legislação que regulamentasse as disposições do art. 218 e art. 219 da Constituição Federal. Assim, em 2003, o governo em substituição ao primeiro Pl apresentou novo projeto, requerendo urgência para sua análise que culminou na lei 10.973/04 ${ }^{9}$.

O principal desafio da lei de inovação tecnológica é superar um equívoco cultural brasileiro que incumbiu somente às universidades toda a responsabilidade pelo desenvolvimento científico e tecnológico do país, enquanto, aos setores de produção caberia apenas incorporar e usufruir do conhecimento produzido. Em outros países, o desenvolvimento científico e tecnológico está devidamente atrelado às relações entre as universidades, empresas e sociedade, através de ações de P\&D focadas nas necessidades e anseios das comunidades regionais, os recursos para financiamento das pesquisas são tanto de origem pública como privada e voltados para resolver problemas concretos e elaborar soluções que possam auxiliar o progresso econômico e social do país.

Os investimentos em P\&D possuem o condão de gerar muitas divisas econômicas e estratégicas para país que poderão vir a ser transformadas em projetos de redução das desigualdades sociais brasileiras. O ano de 2004 deve ser considerado um “divisor de águas", pois finalmente o Estado resolveu adotar posturas de ousadia a fim de instaurar a independência econômica e social do Brasil.

A presente lei traz vários instrumentos visando o fomento à inovação, à pesquisa científica e tecnológica. São vários mecanismos consubstanciados em lei que possuem a função de atuarem como "molas-propulsoras" para P\&D em C\&T\&I. A lei apresenta três eixos essenciais. Os eixos principais da lei de inovação tecnológica são os seguintes:

8 BARBOSA, Denis Borges. Direito da Inovação. Editora Lúmen Júris. Rio de Janeiro, 2006. Uma breve Introdução: por que a lei? Pág. XIX. 
$\Rightarrow$ Estímulo à construção de ambientes especializados e cooperativos de Inovação (art. $3^{\circ}$ ao $\operatorname{art.} 5^{\circ}$ );

$\Rightarrow$ Estímulo à participação das ICT's no processo de Inovação (art. $6^{\circ}$ ao art. $\left.18^{\circ}\right)$

$\Rightarrow$ Estímulo à Inovação nas empresas (art. $19^{\circ}$ ao art. 21);

De outro norte, cabem algumas considerações acerca de alguns órgãos e institutos do presente marco regulatório, para efeitos da lei. Denominou-se como agências de fomento todo e qualquer órgão ou instituição de natureza pública ou privada que possuam entre seus objetivos o financiamento de ações que visem promover o desenvolvimento da ciência, tecnologia e inovação (art. $2^{\circ}$, I); invenção é todo modelo de utilidade, desenho industrial, programa de computador, topografia de circuito integrado, nova cultivar ou cultivar essencialmente derivada e qualquer outro desenvolvimento tecnológico que acarrete ou possa acarretar o surgimento de novo produto, processo ou aperfeiçoamento incremental (art. $2^{\circ}$, II); criador como sendo todo o pesquisador que seja inventor, obtentor ou autor de criação $\left(\operatorname{art.} 2^{\circ}\right.$, III); inovação todo e qualquer mecanismo de introdução de novidade ou aperfeiçoamento no ambiente produtivo ou social que resulte em novos produtos, processos ou serviços (art. $2^{\circ}$, IV); Instituição Científica Tecnológica - ICT - como todo o órgão ou entidade da administração pública que tenha por missão institucional executar atividades de pesquisa básica e aplicada de caráter científico ou tecnológico (art. 2º V); Núcleo de Inovação Tecnológica - NIT - como o órgão ou núcleo, constituído por uma ou mais de uma ICT com a finalidade de gerir sua política de inovação (art. $2^{\circ}$, VI); Instituições de apoio criadas com base na Lei $\mathrm{n}^{\circ}$. 8.958/94, com a finalidade de dar apoio a projetos de pesquisa, ensino e extensão e de desenvolvimento institucional, científico ou tecnológico (art. 2 $2^{\circ}, \mathrm{VII}$ ); conceituou p pesquisador público o ocupante de cargo efetivo, cargo militar ou emprego público que realize pesquisa básica ou aplicada de caráter científico ou tecnológico (art. $2^{\circ}$, VIII) e inventor independente toda a pessoa física, não ocupante de cargo efetivo, cargo militar ou emprego público, obtentor ou autor de criação (art. $2^{\circ}$, IX).

Caracterizados sob o prisma legal, vale lançar algumas caracterização de alguns de seus agentes. As ICT's são todos os órgãos ou instituições de natureza pública que possuem como missão institucional desenvolver atividades de pesquisas básicas ou aplicadas de caráter científico ou tecnológico, logo, presumem-se por excelência, como 
sendo ICT's todos os centros universitários. A lei caracteriza o conceito de ICT em seu art. $2^{\circ}$, inciso $\mathrm{V}$;

$V$ - Instituição Científica e Tecnológica - ICT: órgão ou entidade da administração pública que tenha por missão institucional, dentre outras, executar atividades de pesquisa básica ou aplicada de caráter científico ou tecnológico;

Logo, verifica-se que a lei de inovação tecnológica afastou do conceito de Instituição Científica e Tecnológica as instituições universitárias privadas e comunitárias. Tal dispositivo está recebendo inúmeras críticas e pressões por parte das universidades privadas para que sua redação seja alterada. Contudo, o governo ainda não se manifestou sobre a polêmica e tais instituições não estão amparadas pela lei de inovação para auferir investimentos públicos do Pacti $^{10}$ para projetos de P\&D\&I (pesquisa; desenvolvimento e inovação).

\subsection{Do estímulo à construção de ambientes especializados e cooperativos de} inovação.

O primeiro eixo apontado pela lei de inovação tecnológica, refere-se à construção de ambientes especializados e cooperativos de inovação. De imediato, tal eixo disciplina e orienta os termos legais para a interação entre o setor público e o privado a fim de constituir alianças estratégicas e projetos de cooperação envolvendo empresas nacionais, ICT's e organizações de direito privado sem fins lucrativos com intuito de realizarem atividades de $\mathrm{P} \& \mathrm{D}$, com a finalidade de alcançarem à geração de produtos e processos inovadores. Assim, a norma apontou dois modos distintos de atuação, quais sejam, em primeiro lugar, "a constituição de alianças estratégicas” e, não menos importante, "o desenvolvimento de projetos de cooperação" ${ }^{11}$. Menciona o caput do art. $3^{\circ}$ da lei 10.973/04 da seguinte maneira:

Art. 3o A União, os Estados, o Distrito Federal, os Municípios e as respectivas agências de fomento poderão estimular e apoiar a constituição de alianças estratégicas e o desenvolvimento de projetos de cooperação envolvendo empresas nacionais, ICT e organizações de direito privado sem fins lucrativos voltadas para atividades de pesquisa e desenvolvimento, que objetivem a geração de produtos e processos inovadores.

10 Ver nota 5.

11 BARBOSA, Denis Borges. Direito da Inovação. Editora Lúmen Júris. Rio de Janeiro, 2006.

(C) 2008. Departamento de Direito da UFSM. Todos os direitos reservados. 
Parágrafo único. $O$ apoio previsto neste artigo poderá contemplar as redes e os projetos internacionais de pesquisa tecnológica, bem como ações de empreendedorismo tecnológico e de criação de ambientes de inovação, inclusive incubadoras e parques tecnológicos.

Para Denis Borges Barbosa (2006, pág. 29) o art. $3^{\circ}$ da lei de inovação tecnológica "os termos de inter-relação do setor público e do setor privado enquanto perseguindo a inovação". Adiante, com a mesma clareza, Barbosa menciona que "se trata de norma de aponderamento, tendo como destinatários a União, os Estados, o Distrito Federal, os Municípios e as respectivas agências de fomento; a lei comete a tais entes a missão de apoio aos atores do processo inovador".

De certa maneira, a constituição dos ambientes especializados para fomentar o progresso científico e tecnológico do país propicia maiores poderes de ingerência do governo e de suas agências de fomento, pois os investimentos serão destinados apenas, a priori, s instituições públicas. As ações de $\mathrm{P} \& \mathrm{D}$ ficarão adstritas aos interesses e necessidades do governo, visto que os recursos somente serão liberados após análise dos órgãos de fomento.

Neste sentido discorre Barbosa (2006, pág. 31) sobre a cooperação para constituição de ambientes especializados, “(...) que os ambientes especializados e cooperativos, com o uso potencial de criação das instituições públicas, especialmente universidade e centros de pesquisa, pelo setor econômico, numa via de mão dupla, perquirindo a inovação e o progresso em C\&T (ciência e tecnologia)".

Além disso, as alianças estratégicas traçadas em ajustes de cooperação ou parceria entre as ICT's e instituições públicas ou privadas, ou ODP (organizações de direito privado sem fins lucrativos) deverão sempre estar respaldadas na legalidade e nos princípios norteadores da administração pública. Logo, os acordos e convênios que envolvam o interesse público deverão atender toda a legislação que rege a prática de atos administrativos, em especial, as disposições da lei 8.666/93.

Adiante, a lei de inovação aborda as bases legais para a cessão e compartilhamento das instalações das ICT's. O art. $4^{\circ}$ leciona que as ICT's poderão, mediante remuneração e por prazo determinado, através de contrato ou convênio, compartilhar ou permitir a utilização de seus laboratórios, equipamentos, instrumentos, materiais e a utilização de suas dependências por empresas nacionais, preferencialmente empresas de pequeno e médio porte, e as organizações de direito privado sem fins 
lucrativos voltados para o desenvolvimento de atividades de pesquisas, sem prejuízo das finalidades institucionais da Instituição.

Art. 4o As ICT poderão, mediante remuneração e por prazo determinado, nos termos de contrato ou convênio:

I - compartilhar seus laboratórios, equipamentos, instrumentos, materiais e demais instalações com microempresas e empresas de pequeno porte em atividades voltadas à inovação tecnológica, para a consecução de atividades de incubação, sem prejuízo de sua atividade finalística;

II - permitir a utilização de seus laboratórios, equipamentos, instrumentos, materiais e demais instalações existentes em suas próprias dependências por empresas nacionais e organizações de direito privado sem fins lucrativos voltadas para atividades de pesquisa, desde que tal permissão não interfira diretamente na sua atividade-fim, nem com ela conflite.

Parágrafo único. A permissão e o compartilhamento de que tratam os incisos I e II do caput deste artigo obedecerão às prioridades, critérios e requisitos aprovados e divulgados pelo órgão máximo da ICT, observadas as respectivas disponibilidades e assegurada à igualdade de oportunidades às empresas e organizações interessadas.

Este dispositivo determina o modo pelo qual se constituirão os ambientes especializados de inovação previstos pela lei. De imediato, vislumbra-se que tal dispositivo possa vir a ser alvo de inúmeras críticas por parte da população, que de modo precipitado, entenda que seja um mecanismo de aponderamento do setor privado das instalações e materiais públicos das ICT’s. Assim, os protocolos de intenção, convênios, acordos e contratos deverão estar consubstanciados em detalhados planos de trabalho, que deverão constar, entre outras cláusulas, às obrigações específicas de cada partícipe ou as atividades a serem desenvolvidas em comunhão de esforços no caso de se tratar de convênios; os orçamentos detalhados e as fontes de recursos; datas para as prestações de contas e apresentação de relatórios parciais e finais, das atividades desenvolvidas; cláusulas com o dever de confidencialidade em face do acesso às instalações por terceiros; e deverá constar, expressamente, de acordo com a legislação pertinente, o tratamento a propriedade intelectual decorrente de tais atividades, cabe frisar que a propriedade intelectual auferida no âmbito da ICT a ela pertence. Tais contratos e convênios que possuem como objeto a permissão ou utilização das instalações das ICT's deverão obrigatoriamente ser submetidos à aprovação dos conselhos superiores das entidades. 


\subsection{Do estímulo à participação das ICT's no processo de inovação.}

No presente capítulo, a lei 10.973/04 disciplinou as bases legais para a participação das ICT's no processo de inovação. $\mathrm{O}$ art. $6^{\circ}$ da lei facultou a possibilidade de a ICT celebrar contratos de transferência de tecnologia ou de licenciamento para outorga de direito de uso ou de exploração de criação por ela desenvolvida.

Art. 6o É facultado à ICT celebrar contratos de transferência de tecnologia e de licenciamento para outorga de direito de uso ou de exploração de criação por ela desenvolvida.

$\S 1$ lo A contratação com cláusula de exclusividade, para os fins de que trata o caput deste artigo, deve ser precedida da publicação de edital.

\$2o Quando não for concedida exclusividade ao receptor de tecnologia ou ao licenciado, os contratos previstos no caput deste artigo poderão ser firmados diretamente, para fins de exploração de criação que deles seja objeto, na forma do regulamento.

§ 3 o A empresa detentora do direito exclusivo de exploração de criação protegida perderá automaticamente esse direito caso não comercialize a criação dentro do prazo e condições definidos no contrato, podendo a ICT proceder a novo licenciamento.

$\S 4$ o O licenciamento para exploração de criação cujo objeto interesse à defesa nacional deve observar o disposto no $\$ 3$ o do art. 75 da Lei no 9.279, de 14 de maio de 1996.

§ 5 o A transferência de tecnologia e o licenciamento para exploração de criação reconhecida, em ato do Poder Executivo, como de relevante interesse público, somente poderão ser efetuados a título não exclusivo.

Assim, a ICT como detentora de tecnologias ou de direitos exclusivo sobre suas criações poderá, mediante instrumentos legais, ou seja, contratos, transmitir o conhecimento intelectual produzido para o benefício dos setores de produção, desde que atendam com a função social da propriedade intelectual. Os negócios jurídicos realizados pela ICT's deverão ser baseados na égide das normas de direito administrativo, logo, devem ser atender aos princípios do art. $37^{\circ}$ da Constituição Federal, legalidade, transparência, moralidade, publicidade e eficiência, bem como todas as normas jurídicas vigentes que disciplinam as regras dos atos administrativos.

Desse modo, visando resguardar os princípios da administração pública e dar isonomia ao processo celebração de contratos para transferência de tecnologia e de outorga de direitos de uso ou exploração comercial de criações próprias, a lei estabeleceu cinco parágrafos para trata das modalidades e das formas dos contratos.

Quando se tratar de contratação mediante cláusulas de exclusividade, a celebração do contrato deverá obrigatoriamente ser precedida da publicação de edital, porém, o edital deverá informar somente acerca das obrigações gerais assumidas pelas

(C) 2008. Departamento de Direito da UFSM. Todos os direitos reservados. 
partes contratantes, em hipótese alguma, poderá discorrer discriminadamente acerca do objeto contratado, o sigilo é essencial a fim de se proteger o conhecimento para que a tecnologia nacional não se torne alvo fácil da pirataria internacional. No $\S 2^{\circ}$ a lei trata dos contratos celebrados sem cláusula de exclusividade poderão ser firmados diretamente entre a ICT e a entidade receptora, para fins de exploração de criação que deles seja objeto. Desse modo, a fim de manter a isonomia e transparência dos atos administrativos, salienta-se que todos os negócios jurídicos elaborados com base nesse dispositivo deverão ser publicados em imprensa oficial ou jornal de grande circulação regional, toda a população deve ter acesso às informações para transparecer a idoneidade e lisura dos atos administrativos praticados pelas ICT's.

$\mathrm{O} \S 3^{\circ}$ do art. $6^{\circ}$ aborda a penalidade acerca do dever de a entidade receptora da tecnologia ou da criação comercializa e colocá-la a disposição da sociedade. Tal mecanismo visa garantir a efetividade do conhecimento produzido, logo, garantir que a propriedade intelectual desempenhe a sua função social, bem como para resguardar a sociedade de que o receptor de tais tecnologias ou direitos não realize manobras de especulação comercial. $\mathrm{O} \S 4^{\circ}$ trata que a celebração de contrato que tenha como objeto tecnologia ou criação que sejam de interesse nacional devem atentar as normas que disciplinam a matéria, sob pena de serem responsabilizados por crime contra a segurança nacional e incorrerem nas penas previstas em lei ${ }^{12} . \mathrm{O} \S 5^{\circ}$ elenca que quando houver interesse público a contratação não poderá ser realizada com cláusula de exclusividade.

$\mathrm{O}$ artigo $7^{\circ}$ rege a atividade da ICT como tomadora de direitos de uso ou de exploração de criações protegidas. Desse modo, a ICT dotada de poderes administrativos pode celebrar atos com terceiros a fim de adquirir licenças para usufruir de direitos exclusivos de terceiros.

\section{Art. 7o A ICT poderá obter o direito de uso ou de exploração de criação} protegida.

Menciona Denis Borges Barbosa (2006, pág. 75) sobre a celebração de tais negócios jurídicos que (...) não há quaisquer restrições quanto aos concedentes de tais licenças, que poderão ser instituições privadas e públicas, nacionais ou não, assim como

12 Lei 7.170/83 dispõe acerca dos crimes contra a segurança nacional. Disponível em http://www.planalto.gov.br/ccivil_03/Leis/L7170.htm. Acessado em 28 de junho de 2008.

(C) 2008. Departamento de Direito da UFSM. Todos os direitos reservados. 
pessoas naturais, inclusive os próprios pesquisadores, que forem eventualmente titulares de tais direitos. Contudo, conforme escreve o professor Barbosa, apesar de tal prerrogativa, a aquisição de tais direitos deverá atender ao interesse da instituição e o interesse público, bem como deverá passar pelo crivo dos conselhos superiores da instituição. Logo, por exemplo, s ICT's não poderão realizar negócios jurídicos a fim de adquirem patentes.

No art. $8^{\circ}$ a lei possibilita a faculdade de as ICT's se tornarem prestadoras de serviços voltados à inovação e à pesquisa científica e tecnológica. As tomadoras de serviços das ICT's poderão ser tanto entidades públicas como privadas. Porém, os contratos de prestação de serviços deverão ser apreciados pelos conselhos superiores das instituições a fim de garantir a transparência e lisura dos atos administrativos.

Art. 8 o É facultado à ICT prestar a instituições públicas ou privadas serviços compatíveis com os objetivos desta Lei, nas atividades voltadas à inovação e à pesquisa científica e tecnológica no ambiente produtivo.

$\S 1$ A A prestação de serviços prevista no caput deste artigo dependerá de aprovação pelo órgão ou autoridade máxima da ICT.

No mesmo sentido, às ICT's poderão firmar parcerias com entidades públicas ou privadas visando o desenvolvimento de atividades conjuntas de cunho científico ou tecnológico. Tal prerrogativa restou disciplinada no art. $9^{\circ}$ da lei de inovação tecnológica.

Art. 9o É facultado à ICT celebrar acordos de parceria para realização de atividades conjuntas de pesquisa científica e tecnológica e desenvolvimento de tecnologia, produto ou processo, com instituições públicas e privadas.

(...)

$\S 2$ o As partes deverão prever, em contrato, a titularidade da propriedade intelectual e a participação nos resultados da exploração das criações resultantes da parceria, assegurando aos signatários o direito ao licenciamento, observado o disposto nos $\$ \$ 4$ o e 5 o do art. 60 desta Lei.

$\S 3$ o A propriedade intelectual e a participação nos resultados referidas no $\S$ $2 o$ deste artigo serão asseguradas, desde que previsto no contrato, na proporção equivalente ao montante do valor agregado do conhecimento já existente no início da parceria e dos recursos humanos, financeiros e materiais alocados pelas partes contratantes.

Nos $\S 2^{\circ}$ e $\S 3^{\circ}$ do mencionado dispositivo, a lei estabeleceu o tratamento da propriedade intelectual decorrente dos resultados das parcerias firmadas com base no 
caput do art. $9^{\circ}$. Dita a lei que todas as cláusulas e disposições sobre titularidade, exploração dos resultados deverão estar expressas, sob pena de nulidade qualquer disposição em contrário.

\subsubsection{Da criação dos Núcleos de Inovação Tecnológicos.}

De outro norte, cabe abordar em capítulo próprio sobre o "coração" do instrumento executor da lei na ICT. A lei 10.973/04 prescreve em seu art. $16^{\circ}$ que as ICT's deverão dispor de um Núcleo de Inovação Tecnológica (NIT), próprio ou em associação com outras ICT's, com a finalidade de gerir a sua política de inovação tecnológica.

Ou seja, o processo de inovação e fomento das pesquisas científicas e tecnológicas somente serão possíveis ou viabilizadas mediante ação de órgão específico dentro da instituição, assim, todas as universidades deverão institucionalizar um núcleo de inovação tecnológica com a responsabilidade de gerir a sua política de inovação. O art. 16, além de impor a criação dos NIT's (Núcleo de Inovação Tecnológica) institui todas as suas competências.

Art. 16. A ICT deverá dispor de núcleo de inovação tecnológica, próprio ou em associação com outras ICT, com a finalidade de gerir sua política de inovação. Parágrafo único. São competências mínimas do núcleo de inovação tecnológica:

I - zelar pela manutenção da política institucional de estímulo à proteção das criações, licenciamento, inovação e outras formas de transferência de tecnologia;

II - avaliar e classificar os resultados decorrentes de atividades e projetos de pesquisa para o atendimento das disposições desta Lei;

III - avaliar solicitação de inventor independente para adoção de invenção na forma do art. 22;

IV - opinar pela conveniência e promover a proteção das criações desenvolvidas na instituição;

$V$ - opinar quanto à conveniência de divulgação das criações desenvolvidas na instituição, passíveis de proteção intelectual;

VI - acompanhar o processamento dos pedidos e a manutenção dos títulos de propriedade intelectual da instituição.

Da interpretação consubstanciada na literalidade do texto normativo apresentado, conclui-se que caberá ao NIT a competência exclusiva de gerir a política de inovação da ICT. Assim, o NIT desenvolverá dois grandes pápeis no desenvolvimento das políticas de inovação científica e tecnológica da ICT, um deles

(C) 2008. Departamento de Direito da UFSM. Todos os direitos reservados. 
será desenvolvido internamente, junto à própria comunidade acadêmica e o outro deverá ser desenvolvido externamente, junto aos setores de produção da comunidade local.

No âmbito interno, a atuação do NIT junto à ICT deverá ser no sentido de capacitar e qualificar recursos humanos a fim de usufruir na sua amplitude a nova realidade imposta pela lei de inovação tecnológica. Logo, caberá ao NIT desenvolver uma série de ações no intuito de consolidar o desenvolvimento das pesquisas cientificas e tecnológicas na ICT, através da criação de incubadoras, de parques tecnológicos e outros mecanismos que instiguem a produção científica própria da ICT ou em parceria com as empresas locais.

No âmbito externo, o NIT estabelecer várias relações com mais diversos setores da sociedade com a finalidade de firmar parcerias e convênios para direcionar investimentos em P\&D na instituição e consolidar os objetivos do diploma legal. Portanto, o NIT deverá integralizar e articular um conjunto de ações para fomentar a interação do tripé Universidade, Sociedade e os Setores de produção.

\subsection{Do estímulo à inovação nas empresas.}

No seu terceiro e último eixo, a lei de inovação tecnológica propõe dois dispositivos legais que possuem a finalidade de estimular à inovação de no âmbito das empresas. O artigo 19 disciplina os instrumentos nos nortes da inovação na seara do setor produtivo.

Art. 19. A União, as ICT e as agências de fomento promoverão e incentivarão o desenvolvimento de produtos e processos inovadores em empresas nacionais e nas entidades nacionais de direito privado sem fins lucrativos voltadas para atividades de pesquisa, mediante a concessão de recursos financeiros, humanos, materiais ou de infra-estrutura, a serem ajustados em convênios ou contratos específicos, destinados a apoiar atividades de pesquisa $e$ desenvolvimento, para atender às prioridades da política industrial $e$ tecnológica nacional.

$\S 1$ o As prioridades da política industrial e tecnológica nacional de que trata o caput deste artigo serão estabelecidas em regulamento.

$\S 2 o$ A concessão de recursos financeiros, sob a forma de subvenção econômica, financiamento ou participação societária, visando ao desenvolvimento de produtos ou processos inovadores, será precedida de aprovação de projeto pelo órgão ou entidade concedente.

$\S 3 o$ A concessão da subvenção econômica prevista no § 10 deste artigo implica, obrigatoriamente, a assunção de contrapartida pela empresa beneficiária, na forma estabelecida nos instrumentos de ajuste específicos. 
$\$ 40$ O Poder Executivo regulamentará a subvenção econômica de que trata este artigo, assegurada a destinação de percentual mínimo dos recursos do Fundo Nacional de Desenvolvimento Científico e Tecnológico - FNDCT.

$\S 5 o$ Os recursos de que trata o $\$ 40$ deste artigo serão objeto de programação orçamentária em categoria específica do FNDCT, não sendo obrigatória sua aplicação na destinação setorial originária, sem prejuízo da alocação de outros recursos do FNDCT destinados à subvenção econômica.

Diferentemente dos outros dispositivos legais, o art. 19, conforme leciona o professor Denis Borges Barbosa (2006, pág. 173), "este artigo propõe os termos da assistência prestada pelas ICTs ao setor privado, no tocante às prioridades da política industrial e tecnológica nacional. Está aqui a diferença que justifica o tratamento especial previsto neste artigo". Com a mesma solidez, enaltece o professor as principais diferenças entre os mecanismo da lei de incentivo à inovação, às pesquisas científicas e tecnológicas voltadas ao ambiente produtivo.

No Art. $3^{o}$ se regula a cooperação através de alianças estratégicas e projetos de desenvolvimento. No Art. $4^{o}$ se prevê o acesso do setor privado às instalações física das ICTs. O Art. $8^{\circ}$ rege a atividade da ICT enquanto prestadora dos serviços no caso de aquisições de tecnologia, serviços de pesquisa, etc., em que o tomador de serviços seja terceiro, pessoa jurídica pública ou privada.

O Art. $9^{\circ}$ trata de parceria, ou seja, junções de esforços entre uma ICT e terceiros com fins de desenvolvimento inovativo, sem criação de uma pessoa jurídica própria. No caso de cooperação entre entes públicos e privados que tome a forma de uma pessoa jurídica específica, a norma aplicável é a do Art. $5^{\circ}$. No caso de assistência prestada pela ICT a terceiros, inclusive empresas privadas, sem objetivos comuns, aplica-se este 19. No caso de fornecimento de tecnologia ou licenciamento de criações desenvolvidas pela ICT, aplica-se o Art. $6^{\circ}$. (BARBOSA, 2006, pág. 173-174).

Diante disso, impende-se que se trata de norma de natureza um tanto quanto de ordem econômica, pois abre espaço para ingerência estatal sob quais serão os projetos a serem incentivados com recursos destinados $\mathrm{P} \& \mathrm{I}$. O controle estatal resta caracterizado porque as atividades de $\mathrm{P} \& \mathrm{D}$ deverão atender as prioridades da política industrial e tecnológica nacional.

\section{CONSIDERAÇÕES FINAIS}

Diante disso, torna-se vital para o progresso econômico e social do país a consolidação de políticas públicas que visem o desenvolvimento. Nessa esteira, a lei de 
inovação tecnológica assume papel fundamental para a efetivação de tal processo. Tal instrumento jurídico estabelece diretrizes que vão de encontro a tradicional cultura brasileira que delegou somente às universidades a responsabilidade pelo progresso em C\&T\&I.

São vários os mecanismos legais que visam estimular a interação entre universidades, empresas e sociedade a fim integras ações para o desenvolvimento nacional. Porém, todas as ações deverão ser executadas com total transparência e conformidade com a legislação pátria que regula os atos da administração pública.

Deve-se ressaltar que o interesse público prepondera sobre os interesses particulares, assim os atos administrativos deverão estar pautados na legalidade, na moralidade, na eficiência, na publicidade e na impessoalidade. Há muitas questões a serem abordadas ainda, porém esse não foi o objetivo do presente artigo que se limitou, por enquanto, a somente uma breve apresentação do diploma legal que delineia e regulamenta as disposições constitucionais contidas nos artigos 218 e 219. 


\section{REFERÊNCIAS BIBLIOGRÁFICAS}

BARBOSA, Denis Borges. Direito da Inovação (Comentários Lei n. 10.793/2004, Lei Federal de Inovação). Rio de janeiro: Lúmen Júris, 2006.

BARBOSA, Denis Borges. Bases Constitucionais da Propriedade Intelectual. Disponível em: http://denisbarbosa.addr.com/bases2.pdf>. Acesso em: 10 de maio. 2008.

BASSO, Maristela. O Direito Internacional na propriedade Intelectual. Porto Alegre: Livraria do Advogado, 2000.

BURKE, Peter. Uma história Social do conhecimento de Gutenberg a Diderot. Rio de Janeiro: Jorge Zahar, 2003.

LAKATOS, Eva Maria e MARCONI, Marina de Andrade. Fundamentos de Metodologia Científica. 6 ${ }^{\text {a }}$ ed. São Paulo: Atlas, 2007.

MEIRELlES, Hely Lopes. Direito Administrativo Brasileiro. São Paulo. Editora Malheiros: 33ª Edição, 2007. 